\title{
Investigación de las orientaciones valorativas de los participantes del bullying en el espacio educativo
}

\section{Research on value orientations of bullying participants in educational space}

\author{
Ihor Popovych ${ }^{1 \mathrm{a}}$, Nataliia Zavatska², Mykola Bozoyan ${ }^{3}$, Mariia Vorobel ${ }^{4}$, \\ Olena Blyskun ${ }^{5}$, Karina Klenina ${ }^{6}$
}

Kherson State University, Kherson, Ukraine ${ }^{16}$

Volodymyr Dahl East-Ukrainian National University, Severodonetsk, Ukraine ${ }^{235}$

Lviv State University of Physical Culture named after Ivan Boberskyi, Lviv, Ukraine ${ }^{4}$

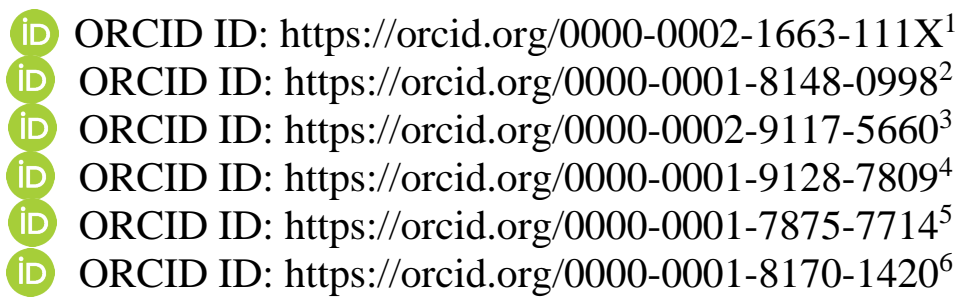

Recibido: 09 de agosto de 2021

Aceptado: 20 de diciembre de 2021

\begin{abstract}
Resumen
El objetivo del presente artículo es argumentar teóricamente e investigar empíricamente las orientaciones valorativas de los participantes del bullying en el espacio educativo. Se argumentaron teóricamente las características psicológicas del fenómeno del bullying tras las orientaciones valorativas de sus participantes. Como método, se describieron las bases metodológicas de la investigación empírica utilizando herramientas válidas de psicodiagnóstico. Se confirmó que todos los participantes del bullying, excepto sus observadores pasivos, tienen una orientación valorativa de "pasar bien el tiempo, descansar", lo que evidencia la interrelación entre la "situación estresante" del bullying y el "agotamiento físico, moral” ( $\mathrm{p} \leq .05$ ). Para las víctimas y testigos que los ayudaban, la orientación valorativa predominante es la "ayuda y misericordia hacia los demás”, y para el acosador, "alto estatuto social” y "gobernar a la gente" ( $\mathrm{p} \leq .05$ ). En conclusión, los resultados empíricos obtenidos y la argumentación teórica contribuyen a la operacionalización de la solución de tareas educativas en la escuela; la implementación de los resultados obtenidos en el trabajo preventivo, correccional de desarrollo reducirá la prevalencia y el nivel de efectos perjudiciales del bullying sobre los sujetos del espacio educativo influyendo en sus orientaciones valorativas.
\end{abstract}

Palabras clave: bullying, orientaciones valorativas, espacio educativo, espacio mediático, agresión, psicología, educación. 


\begin{abstract}
The aim of this paper is to present theoretical substantiation and empirical research on value orientations of bullying participants in educational space. The study theoretically substantiates psychological characteristics of the phenomenon of bullying in the dimension of value orientations of its participants. As methodology, this paper outlines methodological foundations of the empirical research using valid psycho-diagnostic instruments. It was determined that the value orientation "pleasant pastime, rest" prevails in all the bullying participants, except the passive witnesses, that proves the correlation of "stressful situation" of bullying with "physical and moral fatigue" ( $\mathrm{p} \leq .05)$. The dominating value orientation of the victims and witnesses who helped them is "help and mercy to other people", and the orientations "high social status" and "people management" are characteristic of the bullers $(\mathrm{p} \leq .05)$. In conclusion, the study generalizes that the obtained empirical results and theoretical substantiation will contribute to operationalization of solving educational problems at schools; implementation of the obtained results into prophylactic and correction-development work will reduce the spread and the level of a negative effect of bullying on the entities of educational space through the impact on their value orientations.
\end{abstract}

Keywords: bullying, value orientations, educational space, media space, aggression, psychology, education.

\title{
Introduction
}

In the global geo-political dimension, the problem of bullying in educational space is exacerbating and becoming more urgent. Also, bulling in the perception of a modern individual is a new and vague concept, while the content of this phenomenon is quite familiar. Bullying has been characteristic of humanity since ancient times (Shablystyi et al., 2021). Its forms and types have become more intricate and complicated to prove the guilt of offenders. This phenomenon accompanies an individual in both phylogeny and ontogeny: an individual can be bullied not only at school, but at college or university, by workmates, in families, formal or informal groups they belong to.

Attention to the phenomenon of bullying in educational space is determined by a lack of well-formed strategies of dealing with conflict situations involving schoolchildren, they do not understand the importance of constructive relationships and do not possess the ability to defend their borders. Thus, it is necessary to examine the phenomenon of bullying in educational space, its reasons and forms since it is capable of destroying safety of educational space and has a negative effect on the development of main structures of a pupil's personality.

One of the first researchers of it was the Norwegian psychologist Olweus (1993), whose works have contributed to scientific interpretation and spread of the concept of bullying. He also offered the definition of bullying which has become generally accepted: Purposeful 
systematically repeated behavior combining inequality of social status or physical force (Olweus, 1993). Earlier, in some countries there were statutes concerning aggressive behavior of an individual, causing abuse. By his part, Lane (1995) specified the availability of a group of people offending one victim in the definition of "bullying", he also highlights that all participants of this process have a prolonged psychological injury.

Bullying is characterized by inequality of the positions of its participants since a victim is usually weaker and more vulnerable, unable to demonstrate confidence and oppose offenders. Such a child will be oriented towards loneliness or communication with teachers and parents (Sallivan, 2011). Any child can become a victim, since there is a wide range of reasons for bullying: from success and status in a group to affiliation with a particular religion or nationality. Bullers are usually children with love for power, who are used to demonstrating their force and status and inclined to retain them, not allowing anybody to doubt there might.

Throughout the school years and life on the whole a buller and a victim can change their roles depending on the situation, there are more cases when former victims or those who suffer from their peers or older individuals from other groups become bullers. In this way they try to compensate their inferiority in other people's eyes, they raise their self-esteem at the expense of others. Currently there is a tendency to multi-purposefulness of a buller, since one offender can have an array of victims, proving in this way their authority and exceptional nature (Klenina, 2019). Another study outlines social-legal character of bullying and mobbing in the context of the present reality (Shablystyi et al., 2021).

Basic determinants of social behavior of an individual are value orientations (Shkola et al., 2018), therefore it is important to examine them in different bullying participants, since value orientations at school age can be transformed in a constructive way to reduce a destructive effect of this phenomenon (Bubnova, 2015). The formation of value orientations starts in families, under the influence of adults (Blynova et al., 2020c). Later value orientations form in direct contacts with adults, they are experienced and perceived emotionally in practical activities, correlate to social values and develop in the course of an individual's life (Popovych et al., 2020; 2021; 2020b).

The main place of schoolchildren's activities - educational space - has a considerable impact on the inclination to participate in bullying process (Khmiliar et al., 2020). This phenomenon combines not only physical space of a school, but also the system and culture of the interaction administration-teachers-pupils-parents and psychological climate of staff. Having analyzed the literature on this topic (Popovych, 2014; Rubin \& Kepler, 1991), we will try to offer our own definition of the concept of educational space. Educational space is a 
structured system of pedagogical, organizational, educational and material factors contributing to comprehensive development of a pupil's personality in a constructive direction in educational process.

It can also be identified a damaging effect of media space in the situation of impossibility to avoid bullying for a victim (Hudimova et al., 2021). Earlier tortures could stop as soon as a victim left uncomfortable space. Now media are in all the areas of human activities. While pupils have access to Internet, where they are offended, a continuous flow of messages makes them vulnerable to bullying (Klenina, 2019). Nowadays it is difficult to avoid tortures, since changing school does not ensure that a pupil will not be bullied.

It is assumed that value orientations as a basic determinant of pupils' behavior have a crucial impact on their playing any role in the process of bullying in educational space; the use of the research results will contribute to construction of favorable educational space; the suggested theoretical-empirical complex will provide significant scientific facts, application of which will assist in preventative and correction-development work, reduce the phenomenon of bullying and affect the formation of appropriate behavior of school pupils. To conduct empirical research on value orientations of bullying participants in educational space.

\section{Methodology}

When constructing an empirical picture of the research, we were guided by empirical models, tested in the research on self-regulation of an individual's behavior (Halian et al., 2020a; 2020b; Nosov et al., 2020), adaptation potential of interaction participants (Blynova et al., 2020a; 2020d), content features of learning (Blynova et al., 2020b; Miyer et al., 2021a; 2021b), training (Griban et al., 2019) and educational processes (Tsiuniak et al., 2020; Tsymbal, 2017; 2019). The analyzed empirical research is immediately related to the experimental research on value orientations of bullying participants in educational space.

\section{Participants}

This empirical research involved pupils of the secondary schools in Kherson region (Kherson, Ukraine). The sample consisted of 115 participants. The average age of the sample was 12.8 years (range $10-16$ years). The sample contained $73.08 \%$ of girls and $26.92 \%$ of boys.

\section{Organization of research}

The ascertaining cross-section was taken in October-November, 2020. The schoolchildren representing different schools of different regions of Kherson region were 
chosen randomly (Kherson, Ukraine). The research was agreed by the school administrations. The pupils participated in the research voluntarily, they were informed that they could cease it on their own initiative. The research was carried out in compliance with all the ethical principles of WMA Declaration of Helsinki (2013).

\section{Procedures and instruments}

When selecting psycho-diagnostic instruments, it was considered characteristics of attention in schoolchildren and applied methods with an average number of questions or statements requiring agreement or disagreement. The selected methods reflected psychological content parameters relevantly. The test methods we used are valid and reliable.

The questionnaire "The situation of bullying at school” (Petrosyants, 2011) is designed to identify a pupil's position or attitude towards bulling. Using the questionnaire "The situation of bullying at school” it was found three categories of pupils who participated in bullying: victims, bullers and witnesses. The semantic differential scale of measurement was applied.

Another method is "Diagnostics of the real structure of the most important features" (Bubnova, 1994). It is meant to determine prevailing value orientations of an individual. The method contains sixty-six statements/questions to be responded with agreement or disagreement. The results are interpreted after comparing the obtained data with the key dividing the statements and questions into eleven scales.

The method "Diagnostics of the level of aggressio” (Buss-Durkee, 1957; Osnitskiy, 1996) it was used, in order to determine the levels and psychological content features of aggression in the pupils who participate in bullying. The method consists of seventy-five statements implying responses with agreement or disagreement of the participants. This method contains eight scales covering the characteristics of bullers' behavior (physical aggression, irritation, verbal aggression), those of witnesses (indirect aggression, moral scruples), and those of victims (negativism, offense, suspicion). This method also allows measuring the index of aggression and hostility calculated by adding the results of individual scales.

\section{Statistical analysis}

Processing of the research results and their graphical presentation were performed by means of the statistical programs "SPSS” v. 23.0 and MS "Excel”. Significant correlations were determined by Pearson's correlation coefficient $(r)$. Arithmetic mean value of parameters $(M)$ and mean-square deviation (SD) were calculated. Differences between values of parameters at level $\mathrm{p} \leq .05$ were considered statistically significant. 


\title{
Results
}

The set of the research parameters of value orientations of bullying participants in educational space is relevant and methodologically substantiated. When selecting psychodiagnostic instruments we considered the initial conceptual principles of the phenomenon of bullying and value orientations. Fig. 1 presents the data on the distribution of the research respondents $(n=115)$ into groups by their position in bullying. The victims constitute the largest number, the number of bullers is twice less, that proves poly-purposeful behavior of the bullers and a possibility to have two or more targets for torturing. The witnesses represent two groups: those who tried to help the victims and supported them, and those who did not interfere in the process of bullying in any way, they neither approved the buller nor supported the victim. However, such behavior shows the acceptance of the buller's position and approval of it, which only serves as a fertilizer for aggressive behavior.

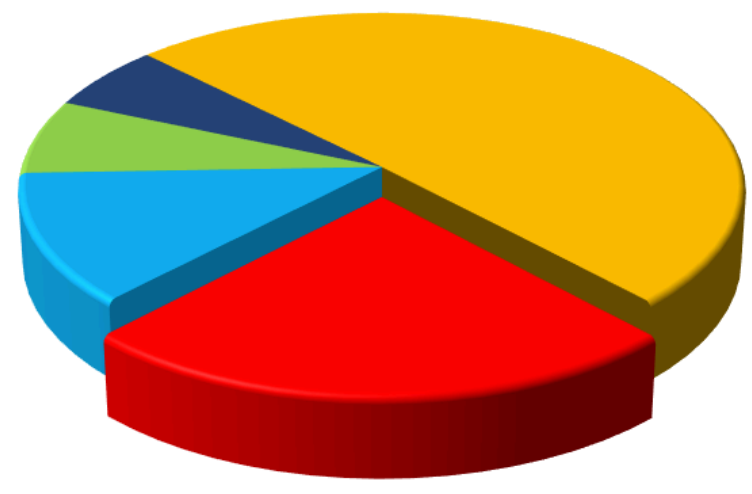

\author{
四 Victims \\ a Bullers \\ Witnesses who helped \\ the victim \\ Massive witnesses \\ Those who did not \\ participate
}

Figure 1. Distribution of the participant roles in bullying by the method "The situation of bullying at school” (Petrosyants, 2011) (n=115)

The descriptive frequency characteristics of the content parameters of the arithmetic mean $(M)$ and mean square deviation $(S D)$ it is shown in the following table. 
Table 1

Values of the scales of the content parameters by the method "Diagnostics of the real structure of the most important features"

\begin{tabular}{|c|c|c|c|c|c|c|c|c|c|c|}
\hline \multirow[t]{2}{*}{ Scale } & \multicolumn{2}{|c|}{ Victims } & \multicolumn{2}{|c|}{ Bullers } & \multicolumn{2}{|c|}{$\begin{array}{l}\text { Witnesses } \\
\text { who } \\
\text { helped }\end{array}$} & \multicolumn{2}{|c|}{$\begin{array}{l}\text { Passive } \\
\text { witnesses }\end{array}$} & \multicolumn{2}{|c|}{$\begin{array}{l}\text { Were not } \\
\text { in } \\
\text { bullying }\end{array}$} \\
\hline & $\mathrm{M}$ & SD & $\mathrm{M}$ & SD & $\mathrm{M}$ & SD & $\mathrm{M}$ & SD & $\bar{M}$ & SD \\
\hline Pleasant pastime, rest & 4.6 & 1.1 & 5.1 & .8 & 4.8 & .9 & 3.0 & .8 & 3.1 & .9 \\
\hline $\begin{array}{l}\text { High material well- } \\
\text { being }\end{array}$ & 3.2 & 1.2 & 2.6 & .9 & 3.0 & .78 & 3.4 & .9 & 3.7 & .5 \\
\hline $\begin{array}{l}\text { Finding and enjoying } \\
\text { the beautiful }\end{array}$ & 3.7 & .9 & 3.4 & 1.1 & 3.4 & 1.2 & 3.1 & 6 & 2.1 & 1.1 \\
\hline $\begin{array}{l}\text { Help and mercy to other } \\
\text { people }\end{array}$ & 4.9 & 1.2 & 3.1 & 1.2 & 4.7 & 1.1 & 2.8 & .7 & 3.3 & .8 \\
\hline Love & 4.4 & 1.4 & 4.8 & 1.1 & 4.9 & 1.1 & 3.5 & .9 & 5.1 & .7 \\
\hline $\begin{array}{l}\text { Knowledge of the new } \\
\text { in the world, nature, } \\
\text { man }\end{array}$ & 3.0 & 1.1 & 3.2 & 1.1 & 3.4 & .9 & 3.5 & .8 & 2.6 & 1.3 \\
\hline $\begin{array}{l}\text { High social status and } \\
\text { people management }\end{array}$ & 3.6 & 1.2 & 5.1 & .8 & 3.3 & .9 & 5.4 & .7 & 2.6 & .5 \\
\hline $\begin{array}{l}\text { Recognition, respect } \\
\text { from people and } \\
\text { influence on others }\end{array}$ & 4.2 & 1.2 & 4.1 & 1.1 & 4.4 & 1.2 & 5.3 & .7 & 5.0 & 1.0 \\
\hline $\begin{array}{l}\text { Social activity to } \\
\text { achieve positive change } \\
\text { in society }\end{array}$ & 3.1 & 1.3 & 3.0 & 1.5 & 2.8 & 1.3 & 3.4 & .9 & 2.9 & .7 \\
\hline Communication & 3.6 & 1.1 & 3.5 & .9 & 3.5 & 1.2 & 3.8 & .7 & 5.1 & 1.1 \\
\hline Health & 3.3 & 1.0 & 3.3 & 1.0 & 3.2 & .8 & 2.9 & .6 & 3.4 & .8 \\
\hline
\end{tabular}

Note: $\mathrm{M}$ - arithmetic mean; SD - mean-square deviation.

The sample presents two prevailing value orientations of the victims - pleasant pastime, rest $(M=4.66 ; S D=1.07)$ and help and mercy to other people $(M=4.98 ; S D=1.16)$. Since victims are often under stress because of bullers' offences and expect possible new tortures, they are characterized by a strong desire to have a rest after a negative experience, therefore most 
representatives of this role determined this value orientation to be prevailing. They represent consumption and hedonistic orientations. Understanding the feelings of those who need help and are offended, victims of bullying often try to give them support and help, show mercy. Knowledge of the new in the world, nature, man $(\mathrm{M}=3.00 ; \mathrm{SD}=1.14)$ and social activity to achieve positive change in society $(\mathrm{M}=3.10 ; \mathrm{SD}=1.30)$ appeared to be the least significant for the victims of bullying.

Among the prevailing value orientations of the bullers there were pleasant pastime, rest $(\mathrm{M}=5.04 ; \mathrm{SD}=.84)$ and high social status and people management $(\mathrm{M}=5.14 ; \mathrm{SD}=.80)$. As in the case of the victims, the situation of bulling is probably stressful for the buller as well, it is also possible that stressful situations and problems beyond school have a negative effect and disorient them. It is known that children who do not feel love and support from their parents, who experience the loss of a significant person, their parents' divorce and suffer from different types of violence beyond school often become bullers. They can compensate their negative experience only through abuse of those who are weaker. It means that bullers have hedonistic and consumption orientations.

The fact that children with narcissist inclinations often become bullers indicates that high social status and people management is a very important value orientation for them. Such schoolchildren try to establish their own authority at a high level and become formal or informal leaders of a class or group. Three value orientations are the most significant for the witnesses who helped the victim, namely: pleasant pastime, rest ( $\mathrm{M}=4.79 ; \mathrm{SD}=.97)$, help and mercy to other people ( $M=4.71 ; S D=1.14)$ and love $(M=4.86 ; S D=1.10)$. The obtained results are quite logical since such pupils showed mercy to the victims and helped them in in a problem situation of bullying. It is a precondition of their inclination for this value orientation. This category of pupils who actively participated in bullying also chose a hedonistic and consumption orientation as one of the prevailing orientations, therefore we can expect that the situation of bullying destabilizes and causes moral and physical fatigue in all the participants of bullying, they desire to spend time more effectively and pleasantly at school and beyond it.

As Table 1 shows, the prevailing value orientations for the witnesses of bullying who were passive observers are high social status and people management ( $\mathrm{M}=5.38 ; \mathrm{SD}=.74)$ and recognition, respect from people and influence on others $(\mathrm{M}=5.25 ; \mathrm{SD}=.71)$. These pupils are afraid of losing their status, therefore they do not want to protect the victim, though they do not support the buller's position. They seem to be between two fires. Probably, such pupils have already made plans for their future, chosen a prestigious job and have a desire for a high social and financial status and respect from other people. To interfere in the situation of abuse in the 
role of a buller will mean their reputation damage, since school activists and leaders often become such witnesses, and to help victims will mean to play their role, that is not very pleasant for them.

The next step in our research is to look at the results of the pupils who did not experience a damaging impact of bullying, therefore they can be considered representatives of the so-called "standard" of value orientations. The prevailing value orientations in this group are recognition, respect from people and influence on others $(\mathrm{M}=5.00$; $\mathrm{SD}=1.00)$, communication $(\mathrm{M}=5.14$; $\mathrm{SD}=1.07)$ and love $(\mathrm{M}=5.14 ; \mathrm{SD}=.69)$. It is worth mentioning that the value orientation "communication" did not prevail in any of the groups of the bullying participants, that indicates to a negative effect of bullying on an individual's communicative skills. At present and in the future, they will face a number of barriers that will not contribute to their development in personal and professional aspects. However, it should be mentioned that value orientations are capable of changing.

When determining the correlations between the indexes of aggression in the groups of bullers and victims and their value orientations we obtained the following results: at the level $\mathrm{p}<.05$ the prevailing value orientation "pleasant pastime" is directly correlated with physical aggression of the bulling victims. We can assume that bullying in a part of the victims developed against a background of their physical aggression.

The correlations of the bullers' prove that they need to have a rest because of their suspicion concerning the things happening to them $(-.453 ; \mathrm{p}<.05)$. This category of pupils is at the stage of understanding that physical aggression and a high social status and people management are not related with each other, probably, they will prefer verbal and indirect aggression (-.380; $\mathrm{p}<.05)$.

We compared the groups of the bullying participants by the index of showing aggression by means of the Mann-Whitney U-test. The differences between the groups of bullers and witnesses trying to help the victim $(\mathrm{U}=45.0)$ are significant at the level $\mathrm{p}<.01$. We determined that the indexes of the bullers' aggression are considerably higher than the indexes of the witnesses helping the victims. It can be explained be different manifestations of value orientations. When comparing the individuals who did not experience the situation of bulling with the bullers and their victims, we found that the indexes of aggression of those who were not involved in bullying are lower than the indexes of the participants $(U=5.0 ; U=23.0)$. These data confirm our assumption concerning a damaging impact of bullying on its participants. We determined that consumption and hedonistic orientations prevail in all the bullying participants, except the passive observers. We consider it to be related to stressfulness of the situation of 
bulling and also physical and moral fatigue of the victims, bullers and witnesses helping the victim. The prevailing value orientation of the victims is help and mercy to other people, that of the bullers is a high social status and people management, that of the witnesses helping the victim is help and mercy to other people and love.

\section{Discussion}

In the scientific literature there are studies on the phenomenon of bullying in educational space and value orientations of secondary education seekers at different stages of their age development (Arora, 1996). However, there are no studies on value orientations of the entities of educational space who participate in bullying. The research on the impact of bullying on personality at the stage of developing and forming the Self-image, creating a steady system of values is considered to be topical. Schoolchildren of this period act like a sponge absorbing large amounts of information.

Value orientations belong to important components of personality structure the development of which can show how well it is developed. They relate to the formation of selfconsciousness and have a crucial impact on the formation of social behavior of an individual (Bubnova, 2015).

Full-fledged development and realization of a child's personal potential at school is only possible under conditions of protection, respect, efficient interpersonal communication and favorable psychological climate. In this context, the research conducted by Larios-Gómez (2021) on educational management in constructing safe educational space is of special scientific interest. The scientist studied empirically and emphasized the key role of a teacher at a secondary school who affects the formation of values, facilitates safe social climate and contributes to education with positive relations. At the same time, another study on bullying in a legal context of the problem highlights those modern transformations experienced all over the world do not exclude the phenomenon of abuse from educational processes (Shablystyi et al., 2021).

The research on value orientations of bullying participants in educational space has much in common with the research on the interrelation between social climate in families and resilience of pupils through the example of schoolchildren aged 13-19 years in Peru. In this case, Moya Lozano and Cunza-Aranzábal (2019) determined a positive correlation between resilience and family social environment $\left(r_{s}=.175 ; \mathrm{p}<.05\right)$ that corresponds to the results of our research. This correlation proves that social climate in families considered by the authors of this discussion as family value orientations is an important factor increasing resilience, at the 
same time it has an impact on an increase in stress resistance and the ability to cope with the situations related to bullying, physical and moral humiliation. Relevance of our discussion is strengthened by the fact that teenagers of a secondary school participated in the research. In the context of this discussion, we should also pay attention to the modern European study (Romania) "How to Tackle Bullying in School - Investigation Study” (Ioana \& Bacter, 2021). Participating in the complex research, pupils of secondary schools, teachers, school psychologists and administrators of secondary education institutions took part in a survey and the researchers, using methods of thematic and content-analysis, by means of the software QSR NVIVO 12, tried to find the answer to the question asked. The results showed the pupils' diffidence and defenselessness; the teachers chose the role of a family as their priority and indicated to the necessity of active joint measures of the participants and interested representatives of society. The fact that values prevail again, as in the research conducted by Moya Lozano and Cunza Aranzábal (2019), is of special interest. It is evident that in the formation of value orientations of bullying participants there is a key for solving this problem which is globally important, unfortunately, in a negative aspect.

This research on value orientations of bullying in educational space is an attempt to determine value orientations of those who offend and suffer from bullying, participate actively in this process and witness passively. It was maintained that consumption and hedonistic orientations are characteristic of all bullying participants, except passive observers, that is explained by physical and moral fatigue caused by bullying. The comparison of this research with the results obtained by other researchers of bulling and value orientations (Arora, 1996; Bubnova, 2015; Klenina, 2019) allows making the following statements.

For the other hand, the value orientation common for the victims and witnesses who tried to help them is "help and mercy to other people", inducing witnesses to help, and making victims keep kindness and not feel hostility in spite of all tortures. The prevailing value orientation of the bullers which probably induces them to offend, is "high social status and people management”, perhaps, they think bullying to be a means to achieve their aim. The comparison with other results (Ioana \& Bacter, 2021; Olweus, 1993), proves that passive observers do not interfere in bulling because of their orientation towards high status, respect and recognition from other people, mainly from those who are authoritative for them. Since we determined that authority in their opinion is related to physical aggression, it is probable that a buller can be authoritative for them, therefore they will not defend victims that can lead to occupying their place later. 
It should be emphasized that, despite some similarities in value orientations of different participants of bullying, their hierarchical lists by the groups are not identical (Bubnova, 2015). The characteristic common for all the groups of the bullying participants is a lack of "communication" among the prevailing orientations, that is more vivid in the pupils who did not witness bullying. Finding and enjoying the beautiful, knowledge of the new in the world, social activity to achieve positive change in society and their health are not very important for bullying participants, they are tired of bullying, since most of them consider "pleasant pastime, rest” to be their value orientation, but they will not escape that trap without a constructive help of adults (Klenina, 2019). The prospects of the research are implementation of the empirical results in educational process of secondary schools; development and testing of socialpsychological workshops aimed at preventing bullying in the participants of educational space.

\section{Research limitation}

The research has a number of limitations. We have formulated three general hypotheses empirically confirmed/disproved. The sample was selected considering the regional representation that should be taken into account while implementing the results in educational practice of other regions. The problem under study is highly topical in the analyzed sources, and we have made an attempt to emphasize its importance in the global dimension. The discussion presented with regard to the research findings is limited by a lack of similar empirical studies on value orientations of bullying participants in educational space.

\section{Conclusions}

We can summarize that the obtained empirical results and theoretical substantiation of value orientations of different bullying participants in educational space will contribute to operationalization of solving educational problems. The research on the impact of media space on inclination for bullying in the entities of educational space dealing with it is interesting from a scientific point of view.

We determined the specificity of the phenomenon of bulling under current conditions and presented the authorial definition of the concept "educational space”. We empirically examined that consumption and hedonistic orientations prevail in all the active bullying participants occupying an important place in their hierarchical lists because of probable physical and mental fatigue caused by the process of bullying. The passive observers chose this position for themselves because of their orientation toward a high social status and people management. 
They can neither support a buller publicly, since it can cause rejection in society nor come down on the side of a victim because it will also lower their status in a significant group.

The specificity characteristic only of the group of pupils who did not experience a damaging impact of bullying is availability of "communication” among the prevailing value orientations, that was not characteristic of any other groups among the prevailing ones. The suggested hypotheses were confirmed. We substantiated that value orientations as a main determinant of an individual's behavior have an impact on the position of the entities of educational space in the phenomenon of bullying, affecting their model of interaction with others.

\section{References}

Arora, C. M. J. (1996). Defining Bullying: Towards a Clearer General Understanding and More Effective Intervention Strategies. School Psychology International, 17 (4), 317-329 https://doi.org/10.1177\%2F0143034396174002

Blynova, O., Chervinska, I., Kazibekova, V., Bokshan, H., Yakovleva, S., Zaverukha, O. \& Popovych, I. (2020a). Social and Psychological Manifestations of Professional Identity Crisis of Labor Migrants. Revista Inclusiones, 7 (3), 93-105. http://www.revistainclusiones.org/index.php/inclu/article/view/1318

Blynova, O., Lappo, V., Kalenchuk, V., Agarkov, O., Shramko, I., Lymarenko, L., \& Popovych, I. (2020b). Corporate Culture of a Higher Education Institution as a Factor in Forming Students’ Professional Identity. Revista Inclusiones, 7 (Especial), 481-496. http://www.revistainclusiones.org/index.php/inclu/article/view/1305

Blynova, O., $\quad$ Moiseienko, V., Los, O., Burlakova, I., Yevdokimova, O., Toba, M., \& Popovych, I. (2020c). Assertiveness as a Factor of Students' Choice of Behavior Strategies in Social Interaction. Revista Inclusiones, 7 (4), 259-272. http://www.revistainclusiones.org/index.php/inclu/article/view/1551

Blynova, O., Popovych, I., Semenova, N., Kashyrina, Ye., Ursulenko, O., \& Kononenko, O. (2020d). Personality Factors of Choosing Adaptation Strategies in a Different Cultural Environment by Labor Migrants from Ukraine. Revista Amazonia Investiga, 9 (32), 4554. http://dx.doi.org/10.34069/AI/2020.32.08.5

Bubnova, S. S. (1994). Methods of diagnostics of individual structure of value orientations of personality. Moscow: IP RAN. http://dip-psi.ru/psikhologicheskiyetesty/post/diagnostika-realnoj-struktury-cennostnyh-orientacij-lichnosti-s-s-bubnova

Bubnova, S. S. (2015). System-forming factors of individuality - value orientations of the individual and the PVK of the subject of activity. Cheboksary: Novoe Vremya. https://search.rsl.ru/ru/record/01007993953 
Griban, G., Prontenko, K., Yavorska, T., Bezpaliy, S., Bublei, T., Marushchak, M., Pustoliakova, L., Andreychuk, V., Tkachenko, P., Zhukovskyi, Ye., Baldetskiy, A., Bloshchynskyi, I. (2019). Non-traditional means of physical training in middle school physical education classes. International Journal of Applied Exercise Physiology, 8 (3.1), 224-32. DOI: 10.26655/IJAEP.2019.10.1

Halian, I. M., Halian, O. I., Gusak, L. Ye., Bokshan, H. I., \& Popovych, I. S. (2020a). Communicative Competence in Training Future Language and Literature Teachers. Revista Amazonia Investiga, 9 (29), 530-541. https://amazoniainvestiga.info/index.php/amazonia/article/view/1417

Halian, I., Machynska, N., Lozynska, S., Nos, L., Derkach, Yu., Prots, M., \& Popovych, I. (2020b). Tolerance of uncertainty as a component of the process of life-creation of future educators. Revista Inclusiones, 7 (Especial), 512-528. http://www.revistainclusiones.org/index.php/inclu/article/view/1307

Hudimova, A., Popovych, I., Baidyk, V., Buriak, O., \& Kechyk, O. (2021). The impact of social media on young web users' psychological well-being during the COVID-19 pandemic progression. Revista Amazonia Investiga, 10 (39), 50-61. https://doi.org/10.34069/AI/2021.39.03.5

Ioana, S., \& Bacter, C. (2021). How to Tackle Bullying in School - Investigation Study. Revista Romaneasca Pentru Educatie Multidimensionala, 13 (1), 384-402. https://doi.org/10.18662/rrem/13.1Sup1/402

Khmiliar, O., Popovych, I., Hrys, A., Pavliuk, M., Zavatska, N., Lytvynenko, O., \& Blynova, O. (2020). Spatial Regulation of Personality Behavior in the Conditions of Progression of the COVID-19 Pandemic. Revista Inclusiones, 7 (Especial), 289-306. http://www.revistainclusiones.org/index.php/inclu/article/view/1760

Klenina, K. V. (2019). Theoretical and methodological analysis of the semantic features of personality perfectionism. Insight: the psychological dimensions of society, 1, 84-89. https://doi.org/10.32999/2663-970X/2019-1-13

Lane, D. A. (1995). The Impossible Child. Stoke-on-Trent: Trentham Books. https://www.bookdepository.com/Impossible-Child-David-Lane/9780948080265

Larios-Gómez, E. (2021). The management of school coexistence in basic education in Mexico: From the perspective of educational marketing. Apuntes Universitarios, 11 (2), 20-47. https://doi.org/10.17162/au.v11i2.630

Miyer, T., Holodiuk, L., Omelchuk, S., Savosh, V., Bondarenko, H., Romanenko, L., \& Romanenko, K. (2021a). An Overview of the Continuous Education System Components in Dimensions "Umwelt", "Mitwelt” and "Eigenwelt”. AD ALTA: Journal of Interdisciplinary $\quad$ Research, $11 \quad$ 52-56. http://www.magnanimitas.cz/ADALTA/110117/papers/A_10.pdf

Miyer, T., Holodiuk, L., Omelchuk, S., Savosh, V., Bondarenko, H., Rudenko, N., \& Shpitsa, R. (2021b). ICT as a Means of Implementing thematic FIN-modeling in the organization of training in institutions of higher pedagogical and adult education. AD ALTA: Journal 
of Interdisciplinary $\quad$ Research, $11 \quad$ 26-32.

http://www.magnanimitas.cz/ADALTA/110118/papers/A_05.pdf

Moya Lozano, M. E., \& Cunza Aranzábal, D. F. (2019). Family social climate and resilience in students of 3rd, 4th and 5th year of secondary school. Apuntes Universitarios, 9 (2), 73-82. https://doi.org/10.17162/au.v9i2.361

Nosov, P. S., Zinchenko, S. M., Popovych, I. S., Ben, A. P., Nahrybelnyi Y. A., \& Mateichuk, V. M. (2020). Diagnostic system of perception of navigation danger when implementation complicated maneuvers. Radio Electronics, Computer Science, Control, (1), 146-161. https://doi.org/10.15588/1607-3274-2020-1-15

Olweus, D. (1993). Bullying at school: What we know and what we can do. Malden, MA: Blackwell Publishing. https://doi.org/10.1002/pits.10114

Osnitskiy, A. K. (1996). Psychology of independence: Methods of research and diagnosticians. Moscow-Nalchik: El-Fa. http://childpsy.ru/lib/books/id/8394.php

Petrosyants, V. R. (2011). Problema bullinga v sovremennoj obrazovatel'noj srede [Bullying in modern school environment]. Vestnik Tomskogo gosudarstvennogo pedagogicheskogo universiteta. Tomsk State Pedagogical University Bulletin, 6 (108), 151-154. $\quad$ https://cyberleninka.ru/article/n/problema-bullinga-v-sovremennoyobrazovatelnoy-srede

Popovych, I., Blynova, O., Zhuravlova, A., Toba, M., Tkach, T., Zavatska, N. (2020a) Optimization of development and psycho-correction of social expectations of students of foreign philology. Revista Inclusiones, 7 (Especial), 82-94. http://www.revistainclusiones.org/index.php/inclu/article/view/1657

Popovych, I., Shevchenko, A., Galvez, L. M., \& Klenina, K. (2021). Estudio de la relación entre la deseabilidad social y las orientaciones valorativas de los jóvenes. Revista Notas $\begin{array}{lllll}\text { Históricas } & y & \text { Geográficas, } & 26 & \text { (1), }\end{array}$ https://www.revistanotashistoricasygeograficas.cl/index.php/nhyg/article/view/339

Popovych, I. S. (2014) Social expectations in primary school age. Proceedings of the 2 nd International Academic Congress "Fundamental Studies in America, Europe, Asia and Africa”, 27 Sept. 2014. USA. Vol. II. New York, 176-180. http://eKhSUIR.kspu.edu/handle/123456789/3306

Popovych, I., Zhigarenko, I., Losiyevska, O., Dovbenko, S., Kashyrina, Ye., Shevchenko, R., \& Piletska, L. (2020b). Research of Achievement Motivation's Impaction the Career Orientations of Future Managers of Organization. Revista Inclusiones, 7 (Especial), 247-263. http://www.revistainclusiones.org/index.php/inclu/article/view/1231

Rubin, K., \& Pepler, D. (1991). The development and treatment of childhood aggression. Hillsdale, NJ: Erlbaum. https://doi.org/10.1002/1098-2337(1993)19:2<157::AID$\underline{\text { AB2480190208>3.0.CO;2-K }}$

Sallivan, K. (2011). The anti-bullying handbook. London. http://dx.doi.org/10.4135/9781446289006 
Shablystyi, V., Obrusna, S., Levchenko, Y., Gluhoverya, V., \& Rufanova, V. (2021). Social and legal nature of bullying. Amazonia Investiga, 10 (37), 78-85. https://doi.org/10.34069/AI/2021.37.01.7

Shkola, O., Griban, G., Prontenko, K., Fomenko, O., Zhamardiy, V., Bondarenko, V., Bezpaliy, S., Andreychuk, V., Tkachenko, P., Zhukovskyi, Ye., Novitska, I., Bloshchynskyi, I. (2019). Formation of valuable orientations in youth during physical training. International Journal of Applied Exercise Physiology, 8 (3.1), 264-272. DOI: 10.26655/IJAEP.2019.10.1

Tsiuniak, O., Pyslar, A., Lialiuk, G., Bondarenko, V., Kovtun, O., Los, O., \& Popovych, I. (2020). Research of interdependence of variables and factor structure of masters' readiness for innovative pedagogical activity. Revista Inclusiones, 7 (3), 427-452. http://www.revistainclusiones.org/index.php/inclu/article/view/1645

Tsymbal, S. V. (2019). Enhancing students' confidence and motivation in learning English with the use of online game training sessions. Information Technologies and Learning Tools, 71 (3), 227-235. https://doi.org/10.33407/itlt.v71i3.2460

Tsymbal, S. V. (2017). Overcoming language anxiety among the English language learners: psycho-pedagogical aspect. Science and Education, 7, 102-106. https://scienceandeducation.pdpu.edu.ua/articles/2017-7-doc/2017-7-st16

World Medical Association Declaration of Helsinki. (2013). Ethical principles for medical research involving human subjects, $310 \quad$ (20), 2191-4. https://doi.org/10.1001/jama.2013.281053 